\title{
Thailand institutional framework for FTA negotiation ${ }^{1}$
}

\author{
Suphachalasai Suphat ${ }^{1}$, Mephokee Chanin ${ }^{2}$, Yoonaidharma Sudharma ${ }^{3}$, Khumon \\ Prapanpong $^{3}$, Chan Natharika ${ }^{3}$, Winyuhuttakit Pakorn ${ }^{3 *}$, Jarungsri Nattakhanya ${ }^{4}$ \\ ${ }^{1}$ Thammasat Institute of Area Studies (TIARA), Thailand \\ ${ }^{2}$ Thammasat University, Thailand \\ ${ }^{3}$ University of the Thai Chamber of Commerce, Thailand \\ ${ }^{4}$ Thammasat Institute of Area Studies (TIARA), Thailand \\ *Corresponding author: paekoe@ hotmail.com
}

\section{ARTICLE INFO}

DOI: $10.46223 / \mathrm{HCMCOUJS.}$ econ.en.8.2.161.2018

Received: May $8^{\text {th }}, 2018$

Revised: July $26^{\text {th }}, 2018$

Accepted: August 16 ${ }^{\text {th }}, 2018$

Keywords:

free trade agreement, institutional framework, negotiation

\section{ABSTRACT}

This article aims to analyze institutional framework relating to the implementation of international trade and investment agreements, especially Free Trade Agreements (FTAs), which Thailand is a member country and going to be a member country, to recommend appropriate guidelines for integration of process and institution to comply with commitments under international trade and investment agreements. The article covers an overview of the institutional mechanism and process of establishing agreement and the implementation of specific areas such as Technical Barriers to Trade (TBT). The article indicates problems of integration of institutional framework in Thailand and renders important recommendations both for general issues (such as Thai government should formulate strategy and create strategic roadmap for trade and investment negotiation) and for specific issues (such as Thailand should conduct a periodical review of existing technical standards to assess their compliance with FTAs).

This article is based on a research project named "Thailand's Institutional Reform in the Face of International Trade and Investment Obligations" of International Institute for Trade and Development (ITD) conducted using several research methodologies including documentary research, field survey, indepth interviews and focus group.

\footnotetext{
${ }^{1}$ Some insight information in this paper comes from experience of the authors (Suphat Suphachalasai, Chanin Mephokee and Sudharma Yoonaidharma) that participated in the Japan - Thailand Economic Partnership Agreement (JTEPA) and Thailand - United States Free Trade Agreement negotiations as a consultant to chief negotiators. Thus, there will not be any sources available for citation.
} 


\section{Overview of institutional mechanism comparison between Thailand, Singapore and South Korea}

This section will explore the overview of the institutional mechanism and process of establishing agreement on trade and investment liberalization in Thailand compared to that of the Republic of Korea (also called South Korea) and the Republic of Singapore (also known as Singapore). South Korea has set the policy goal to make the country a center of international trade and has hastened her trade liberalization since the end of 1990s. Therefore, thanks to her negotiation experiences, South Korea's institutional mechanism is systematic and effective. The country has successfully pushed forward trade preference use of her trade agreements. Singapore, on the other hand, is the Southeast Asian country that adopts free-market policies and practices with the highest degree of trade openness. Consequently, the country strongly advocates the establishment of international trade and investment agreements. For that reason, Singapore, as Thailand's main competitor in Southeast Asian region, set a good example for Thailand to learn and become an interesting case study in terms of the magnitude of trade liberalization.

In general, international trade and investment agreements are developed through four stages. The first stage occurs before actual negotiations take place. This stage will help decide whether or not to negotiate the agreement. The second stage happens during the negotiation and involves various institutions including political and government agencies, interest groups, private sectors, and other stakeholders. The third stage involves the endorsement - a short period before the agreement comes into force or official endorsement period. Finally comes the fourth stage which is after the enforcement of the agreement where institution mechanisms are needed to implement or to push implementation of the said agreement as agreed by the two contractual partners.

\subsection{Before the actual negotiation of the international trade and investment, the agreement takes place (also known as Pre-negotiation period)}

In Thailand, prior to actual negotiation, there are no clear guidelines or strategies for the government to determine which countries should Thailand negotiate trade and investment agreements with and how to prioritize them. In terms of trade strategies, there are no specific goals for each agreement. There are two scenarios for the initiation of negotiation; first from Thailand and second from its trade parties. In both scenarios, the decision on whom or when the negotiation should be initiated usually made by top-level policymakers or advisors such as the prime minister, minister, senior executive officials, or high-level officials in the government. In the first scenario, the negotiation is likely to start when top executive officials of related ministry met with counterparts and initiated trade negotiations with Thailand. After negotiations verbally agreed by both countries, the process begins by setting target-country for negotiation. In the second scenario, trade parties interested in negotiating trade and investment agreements will start the negotiation directly through normal channels. ${ }^{2}$ The findings show that the process of initiating trade negotiation in Thailand is different from that of South Korea and Singapore. In Thailand, Free Trade Agreements (FTAs) negotiation is not included as part of the country's

\footnotetext{
${ }^{2}$ Information from an interview with high level officials in Thai government
} 
trade policy although international trade continues to be important. It can be seen that the country relies heavily on international trade from the Degree of Openness which reached the new high at 106 percent in 2015 (World Bank, n.d.). For that reason, international trade and FTAs are important to the economic growth of the country and should be included as one of the strategic plans for the country's policies.

Department of Trade Negotiations, Ministry of Commerce, was in charge of most past trade negotiations in Thailand. Only two special cases were led by the Ministry of Foreign Affairs, namely, Japan-Thailand Economic Partnership Agreement (JTEPA) (2007) and United States - Thailand Free Trade Agreement (Thai-US FTA) (2006) whose negotiations have been suspended. The negotiations of these two cases were agreed upon by former Prime Minister and Deputy Prime Minister and now handled by the current Ministry of Foreign Affairs.

After a trade negotiation decision was made, Ministry of Commerce would usually outsource the advisory team to conduct feasibility study on the possible impacts of trade agreements on various aspects. For some agreements, the Ministry may also outsource overseas consulting firms to work with a domestic advisory team.

The ambit of trade and investment agreements included provisions on all or many areas and/or topics of negotiation in accordance with the standard approach of international trade and investment negotiations. For example, all of them covers tariff and non-tariff measures to eliminate trade barriers between negotiating parties. Different agreement negotiations have a different focus but usually, provisions on trade in goods, agricultural and non-agricultural products are on the main agenda. The emphasis or weight on negotiations depends on negotiating partners. For example, during the JTEPA negotiations, it was not difficult to conclude the deal on industrial products owing to its lower degree of industry protection. However, for sensitive and protected sectors like agriculture, there were many issues to cover and negotiate. On the other hand, during the Thai-US FTA negotiations, the emphasis was placed on textile, pick-up trucks, intellectual property rights, and financial sector liberalization.

The service sector has long been a sensitive sector in Thailand. Other than ASEAN Economic Community (AEC), service sectors in Thailand are not liberalized, particularly the financial sector because this sector was heavily regulated by Bank of Thailand (BOT) to protect local commercial banks from the competition of foreign commercial banks. Therefore, there are no frameworks for service sector negotiation in JTEPA, Thailand - Australia Free Trade Agreement (TAFTA) (2005), Thailand - New Zealand Closer Economic Partnership Agreement (TNZCEP) (2005) and the remaining agreements.

Similar to Thailand, South Korea is an export-led country that depends greatly on external sectors (Solís, 2013, p. 3). FTAs are regarded as part of the country's trade policy where a clear goal is set and strategic plans are formulated for implementation. The country aims to become an FTA Hub to open her markets and expand her export (Cheong, 2017). In order to achieve the goal, South Korean government creates FTA Roadmap (Solís, 2013, p. 8) and enforces new rules and regulations to facilitate the negotiation process. For example, in 2004, South Korea issued Presidential Directive on Procedures for the Conclusion of Free Trade Agreements (Cheong, 2017) to assign responsibilities for carrying out trade negotiations and to 
set up the negotiation process from pre-negotiating, negotiating, and post-negotiating (Lee, 2010, p. 296). In contrast to Thailand, South Korea's FTA strategy is more goal-oriented, wellplanned, well-drafted and well-prepared.

According to Cheong (2017), FTA Committee of South Korea is the authority responsible for negotiating FTAs. This committee will form a common direction and strategies that promote FTAs, choose to negotiate partners, prepare basic agreements, and check domestic policies related to the negotiation (Lee, 2010, p. 296).

Singapore is a small country with limited natural resources, a small number of workers and a small domestic market size. Thus, the country's economic development policies and strategies mainly concentrate on external sectors. Considering trade liberalization an essential part of trade policy, Singapore is trying to make its main trading partners liberalize their trade and investment. Currently, Singapore signed approximately 16 FTAs with trading partners. The country's strategies and institutional mechanisms for free trade negotiations have evolved over time through the process of learning by doing. ${ }^{3}$ Ministry of Trade and Industry (MTI) is the authority in charge of formulating strategies and FTA Roadmap ${ }^{4}$ proposal for the cabinet to approve. In the process of formulating strategies and Roadmap, MTI will consult the Ministry of Foreign Affairs and hold a public hearing to gather opinions from businesses through agencies under its jurisdiction such as International Enterprise (IE) Singapore and Singapore Economic Development Board (EDB).

Additionally, MTI also sets up three working teams including the policy team, legal team, and negotiation team. The policy team will prepare information, set the position on various aspects negotiable by negotiating partners, and propose negotiating directives to the Economic Ministerial Meeting and negotiating team. Typically, members of the policy team comprise MTI officers. The legal team will look at domestic laws and their conformity with proposed agreements. If necessary, the team will propose the amendment of domestic laws to fit proposed agreements. The last is the negotiating team led by Chief of Negotiation. The rank of Chief of Negotiation must be at the same level and correspond to that of the counterpart.

\subsection{During the actual negotiation}

During the period when Thailand actively engaged in trade and investment negotiation, the country was governed by the Constitution of the Kingdom of Thailand B.E. 2542 (1999). Under the said Constitution, there were norules or regulations showing the need for getting Parliament's approval. The executive branch has the highest authority in negotiations. After the agreements were concluded, the draft of agreements was sent to the Cabinet to rectify and promulgate. However, the Constitution of the Kingdom of Thailand B.E. 2550 (2007) specifies that the framework of trade negotiation must be approved by the Parliament before actual

\footnotetext{
${ }^{3}$ Information from an interview with high-rank officials in Ministry of Trade \& Industry, Singapore

${ }^{4}$ Ministry of Trade \& Industry classified Singapore's trading partners into three groups; the First Wave, that are all main trade partners including Australia, New Zealand, Peru, U.S.A, and ASEAN; the Second Wave, countries in the same region, comprises Brunei, China, India, Japan, South Korea, and Taiwan; and the Third Wave which are countries that locate further away such as Argentina, Columbia, Panama, and countries in Latin America
} 
negotiations and that there must be public hearings. So JTEPA is the last agreement that the negotiation framework never made it to the Parliament. Trade agreements that negotiate after 2007 onward have to firmly follow this rule (B.E. 2550, art. 190; B.E. 2557, art. 23; B.E. 2560, art. 178)

During the negotiation process, stakeholders or other groups who may be impacted by this agreement will have a role to play. Ministry of Commerce provides these groups with information about the impacts and problems that may arise from the agreement.5 It is observed that some interest groups, though they do not take part in the actual negotiations, such as the Federation of Thai Industries (F.T.I), the Thai Chamber of Commerce, the Thai Banker Association, and other important industrial groups or associations will wait outside for daily summary of what happened at the table after their talk ended for the day in the evening. Hence, every day Thai negotiation team would hold a joint meeting by interest groups to make a daily summary. This unusual practice cannot be found in any country and in USA particularly. Generally, the negotiation team will brainstorm and make decisions before actual negotiations. In Thai-US FTA negotiations, USA's positions in negotiating issues are clear and no entities from the private sector or interest groups officially waits to hear the summary of the talk.

Ministry of Commerce will be informed about any conflicts arisen among interest groups. This information and information gained from the ministry's study and the advisory team will then be analyzed to make decisions. However, for sensitive products or services and exchange of market access, final decisions will be made at the policy level by Prime Minister, Ministers, Permanent Secretary of Ministries, or at the high-level meetings.6 For highly protected products, modalities for tariff reduction negotiations will allow a longer implementation period. For instance, TAFTA (2005, art. $509 \&$ annex 5), the tariff cut for 71 items in sensitive agricultural products such as beef, pork, dairy products, tea, and coffee, will be eliminated from 10 to 15 years (from 2005 to 2015-2020). Other measures to lessen conflicts such as trade remedies measures and/or to help sector negatively affected by agreements by increasing their productivities such as New Zealand's commitment to help Thai dairy farmers during adjustment period (TNZCEP, 2005, art. 9.4)

Moving on to South Korea, FTA Bureau has been responsible for trade negotiations and related processes since 2004 while the FTA Committee is in charge of policy setting. After FTA Committee agreed with the trade negotiation agenda, the agenda will be sent to the Minister's Meeting for External Economic Affairs (MMEEA) to make final decisions.

Article 21 of Presidential Directive on Procedures for the Conclusion of Free Trade Agreements specifies that the Chairman of the FTA Committee has obligation to report the progress of the trade negotiation to the National Assembly, the public, stakeholders, and collect feedback from them. In addition, Article 23 states that after the negotiation is concluded, the result must be reported to the National Assembly as well as to the public (Lee, 2010, p. 296).

In South Korea, people can participate in trade negotiations in many ways. First of all,

\footnotetext{
${ }^{5}$ Information from an interview with high level officials in Thai government

${ }^{6}$ Information from an interview with high level officials in Thai government
} 
through public hearings in which FTA Advisory Committee was appointed by the FTA Committee as a feedback mechanism to collect opinions and comments from related industrial sectors and experts. Moreover, interest groups may indirectly involve in setting the direction of the negotiation by pushing political parties which can provide consultation to the President and vote to accept or reject the terms of the agreements when they go through the National Assembly. The President also has his own advisory committees, such as the Advisory Committee for Domestic Economic Affairs, to give him advice on various issues (Park \& Moon, 2006 , p. 6). These are typical ways for the public and interest groups to intervene, lobby for or protect their own interests.

As for Singapore, during the trade negotiation process, MTI acts as the secretary of the negotiation team. The negotiation team must keep in mind while negotiating whether the agreements will conform with its domestic laws or about its own limited resources. The negotiation team must refer to all conflicts of interest arising from the negotiating process to Economic Ministers' meeting to make a decision and may need to send to the Cabinet meeting for ratifying the decision. Policy Team should provide the Economic Cabinet Meeting with informative feedback at all times.

\subsection{Official endorsement period}

Official endorsement procedure in Thailand under the Constitution of Kingdom of Thailand B.E. 2540 (1997) required ratification of the agreements from the Cabinet meeting. However, under the Constitution of Kingdom of Thailand B.E. 2550 (2007), the Parliament must approve the draft of trade and investment agreements before they come into force (B.E. 2550, art. 190; B.E. 2557, art. 23; B.E. 2560, art. 178).

South Korea's official endorsement procedure is similar to that of Thailand to some extent. To enforce the trade and investment agreements, Constitution of Republic of Korea specifies that the trade and investment agreements will take effect upon signature by the President (Article 73) and that rectification must be approved by the National Assembly (Article 60 Paragraph 1) (Park \& Moon, 2006, p. 3).

\subsection{After the trade and investment agreements entered into force (Post-Negotiation)}

There are three key areas related to post negotiation as follows:

\subsubsection{Mechanism to monitor the implementation of the agreement after fully entered} into force

In Thailand, after an agreement coming into full force, all related ministries and departments are responsible to pass it on to all commitments and obligations agreed by them in the agreement. Then many ministers will get involved in the implementation of the agreement including tariff reduction conducted by the Ministry of Finance's Revenue Department, product standards enacted by Ministry of and all agriculture-related issues handled by the Ministry of Agriculture and Cooperatives. In addition, some related domestic laws might be amended where necessary to enforce some trade and investment agreements. However, there are no concrete tools or evidence to monitor whether relevant domestic laws were amended or related 
agencies implemented commitments to the agreement. Only when a complaint was filed then the issue was brought to light. ${ }^{7}$

On the contrary, in South Korea, the National Auditing Office serves as a monitoring mechanism to ensure that responsible agencies implement commitments as per stated. ${ }^{8}$

Monitoring mechanism in Singapore centers at MTI. MTI will monitor and follow up with related agencies to carry out their works toward the commitment. The work will start after the agreement is ratified by the Cabinet at the Cabinet meeting. The legal team will begin to amend domestic laws in accordance with the agreement. MTI has the duty to issue regularly FTA Review - a Progress review and report - for the Cabinet.

\subsubsection{Use of trade agreement preferences}

In terms of FTA Utilization, after South Korea's various trade agreements came into force during 2007-2009 periods, they found out that not many companies could enjoy the benefits of trade and investment agreements. This was really surprising regardless of South Korea's efforts to promote the use of trade agreement preferences through numerous supporting programs including educating and informing about FTAs, giving consultation, and organizing workshops to help businesses and companies understand and increase the preferences utilization. However, some programs were not effective while some others were designed to merely increase the positive attitude of the public towards FTAs. Still, only a few companies were utilizing trade preferences for exporting their products due to their inability to comply with all FTA requirements such as proof of products' origin. As a result, businesses gave some negative feedback on the use of FTA, precisely the complication of the process (Cheong, 2014, p. 11).

Soon enough, South Korea's government was aware of this problem. In 2010, South Korea's trade authority reviewed FTA utilization status, assessed the previous supporting projects, and conducted surveys for opinion and feedback to prepare a government-level policy package for FTA utilization. All data obtained from the said sources were sent to the Ministry of Strategy and Finance (MOSF) to formulate Plan for Enhancing FTA Utilization and modify the main duties of FTA Promotion and Policy Adjustment Authority (FTAPPA) from handling domestic trade-related problems to promoting FTA utilization to the business sector. MOSF and FTAPPAA will cooperate to set up multiple projects to promote the utilization of trade agreements. Two new agencies were established to facilitate this work including National FTA Utilization Center (FTAUC) and FTA Assistance Center. FTAUC and FTAPPAA will then coordinate with each other. While FTAPPA is responsible to set annual trade policies, goals, and guidelines, FTAUC will put them into practice at the national level. At the regional level, FTA Assistance Center was set up in regions to support local businesses to utilize FTAs (Cheong, 2014, pp. 12-13). These efforts have finally paid off. South Korea's FTA utilization rate rose dramatically from 20 percent to 60 percent in 2013 (Cheong, 2014, pp. 20-21).

Singapore's mechanisms promote FTA utilization by providing businesses and the

\footnotetext{
${ }^{7}$ Information from an interview with high level officials in Thai government

${ }^{8}$ Information from interview with South Korea's experts
} 
public with information about the benefits of free-trade agreements and setting up the Productivity Fund. This useful information was provided by IE Singapore to the public through various means such as publishing on website iesingapore.gov.sg.

Unlike South Korea and Singapore, in Thailand, cooperation projects for some trade agreements such as agricultural cooperation projects under TNZCEP or cooperation project under JTEPA have been underutilized. There is no formal agency working to promote the use of FTA preferences. At the same time, even though an online platform about FTA is used in the three countries, South Korea and Singapore move beyond Thailand in terms of facilitating the use of preferences. In the other two countries, mobile applications made information available at all times and, thus, more convenient for businessmen and investors to take full advantage of the FTA benefits. In contrast, Thailand only offers FTA and FTA related information through the website. The content is shown on the website merely stated the products that receive preferential treatment under FTAs and other general information which do not help the business sector much in utilizing the benefits of FTA.

\subsubsection{Domestic measures or remedy to help domestic industries or workers coping with} adverse impacts of trade agreements

It cannot be denied that although free trade may be beneficial to economies, some domestic industries definitely suffer. Therefore, Constitution of Kingdom of Thailand B.E. 2550 (2007) Article 190 stated that in case the trade agreements have a negative effect on people or Small and Medium Enterprises (SMEs), the government must find the way to correct it or provide remedies to them in a suitable and fair manner. Thai government, therefore, provide two financial assistant mechanisms as follows:

a) Ministry of Agriculture and Cooperative's FTA Fund

This financial assistant mechanism was established for structural adjustment and promoting competitiveness in the agricultural sector. The fund aims to develop agricultural structure and increase competitiveness by improving output volume and product quality. This FTA fund will also be used to support research and development, capacity building in the agricultural sector such as training and study trip; and to support infrastructure and career change. During 2006-2016 period, the government allocated 780.12 million baht for this fund for 27 projects (Office of Agricultural Economics, n.d.).

b) Ministry of Commerce's FTA Fund

This fund is allocated to assist the adjustment of economic and service sectors adversely affected by FTAs and put under the supervision of the Department of Foreign Trade, Ministry of Commerce. This fund will be used to assist producers and entrepreneurs in processed agricultural products, industrial products, and service businesses negatively influenced by the agreements. From the establishment of the fund in 2007 to end of the fiscal year 2015, Ministry of Commerce spent 372.86 million baht to fund 46 projects in total (Department of Foreign Trade, n.d.).

Obviously, the number of projects funded by the FTA Funds is not significant compared to the number of signed agreements. One of the reasons is that business owners or 
entrepreneurs do not know the existence of the fund and whether they are eligible to apply for financial assistance. Another reason could be that affected businesses could handle well on their own without asking for any remedies. Also, the process of asking for remedy might be too complicated for public sectors, especially for SMEs, to carry out and access to the fund. Furthermore, these remedies are like medicine cabinet available at every home but they just never use it. Finally, it is only the policy measure showing all parties that every aspect was thoroughly and carefully examined and considered but having no practical value. ${ }^{9}$ FTA Funds in Thailand is small in comparison to that of South Korea. The country set aside 52,000 million $\mathrm{USD}^{10}$ for remedies of domestic economy while the total value of two Thai FTA Funds 33 million USD. Noticeably, there are only two remedial funds in Thailand including the Ministry of Commerce's FTA Fund and the Ministry of Agriculture and Cooperatives' FTA Fund. The majority of the fundusers tend to be government agencies such as Ministry of Agriculture and Cooperatives not ordinary businesses and entrepreneurs. For many projects, their success is not obvious. Besides, there are several assistance commitments by negotiating partners that Thailand is underused. For instance, New Zealand commits to assist in increasing milk product and dairy farm productivity or, under JTEPA, Japan commits to help the agricultural sector under the Agricultural Cooperation sections among others.

Contrariwise, Singapore has no remedy for local businesses. As the country adopts a free and open market approach, the Singapore government assumes that it is the duty of business sectors and entrepreneurs to adapt and adjust to the arising competition. Measure for remedy is not necessary for Singapore. In fact, Singapore entrepreneurs are familiar with the global competition; therefore, trade liberalization through free-trade agreements will not bring extra competition to the country.

\section{Implementation of the specific sector under international trade and investment agreement}

Considering the institutional framework on the implementation of specific sector i.e., Technical Barriers to Trade (TBT) as sample area after the trade and investment agreements entered into force, the details of such specific sector are as follows:

\section{Technical Barriers to Trade (TBT)}

\subsection{Thailand's TBT Commitments in International Trade Agreements}

As domestic technical measures are imposed for a variety of reasons (e.g., protecting environment, safety, national security and so on), TBT becomes a standard provision in all trade agreements to ensure that the measures are not arbitrarily used or implemented as excuses for protectionism. As a WTO member, Thailand commits that technical measures are in compliance with rules of TBT Agreement (World Trade Organization, 2004, p. 14).

(1) Technical regulations must not impose arbitrary conditions to market access (e.g., processes or production methods concerning packaging, marking, labeling). Governmental

\footnotetext{
${ }^{9}$ Information from interview with high-rank officials in the government agency

${ }^{10}$ Information from interview with South Korea's experts
} 
measures cannot require market access to be contingent on fulfilling the requirements set forth in the technical regulations;

(2) Standards can be developed to ensure that process or production methods of imported goods in line with public goals. However, standards that give more advantages to domestic products are discouraged. These standards can be approved by recognized bodies but they must be notified to the WTO's TBT Committee and adhere to the Code of Good Practice for the Preparation ("The Code") in the TBT Agreement;

(3) Conformity assessment procedures can be imposed to determine that imported goods fulfill technical requirements (e.g., inspection, evaluation and assurance). FTAs encourage countries to recognize each other's procedures for assessment. Without recognition, goods might have to be tested twice, first from the exporting country and then the importing country. Thailand is required to create a national enquiry point to keep others informed of assessment procedures.

TBT Agreement provides key principles that become basic TBT commitments in other FTAs. For example, the non-discrimination principle ensures that technical standards are not imposed to protect domestic producers from foreign competition (applying to technical regulations, standards, and conformity assessment procedures). The adoption of international standards is encouraged. WTO jurisprudence normally perceives measures not compliant with international standards to be inconsistent with TBT Agreement, for example, EC - Sardines $(2002)^{11}$ and US-Tuna II (2012) ${ }^{12}$.

\subsection{Adoption of commitments}

Several bodies are responsible for keeping technical regulations in compliance with FTA commitments; namely, the Thai Industrial Standards Institute (TISI) under the Ministry of Industry; the National Bureau of Agricultural Commodity and Food Standards (ACFS) under the Ministry of Agriculture and Cooperatives; the Ministry of Commerce (policy and legislation), and the National Institute of Metrology under the Ministry of Science and Technology. The Office of the National Standardization Council of Thailand along with the Department of Medical Service, the Department of Science Service, and the ACFS is in charge of accreditation of bodies for conformity assessment (World Trade Organization, 2015, p. 54).

TISI works under the scope of the Industrial Products Standards Act B.E. 2511 (1968) to develop technical standards through discussions with concerning industries. In 2015, TISI launched a total of 3075 standards, 1025 of which are international standards (World Trade Organization, 2015, p. 54). Thailand is a member of international standard bodies, namely, the International Organization for Standardization (ISO), the International Electrotechnical

\footnotetext{
${ }^{11}$ Peru claimed that EU's measure of allowing only Sardina pilchardus Walbaum (mainly found in EU) to be marketed as "preserved sardines" violated TBT Agreement as it prevented Peru's Sardinops sagax from marketing this as preserved sardines as well. The WTO ruled that EU's measure was inconsistent with relevant international standards from the FAO/WHO Codex Alimentarius Commission where it included this kind of Peru's sardines.

${ }^{12}$ WTO ruled that, the Agreement on the International Dolphin Conservation Programme as claimed by the US to ban imports from Mexico, was not a relevant international standard since new parties to the Agreement can be acceded only by invitation
} 
Commission (IEC), and the International Telecommunications Union (ITU). Thailand has one effective Mutual Recognition Arrangement (MRA) under APEC on conformity assessment of electrical and electronic equipment, foods and food products, telecommunications equipment, and exchange of information on toy safety.

\subsection{Institutional framework and collaboration}

Thailand's framework depicts a hierarchical system. The Department of Trade Negotiation (DTI), Ministry of Commerce is responsible for FTA negotiations and communicate outcomes of the negotiation to relevant bodies (e.g., TISI \& ACFS) via ad hoc meetings or explanatory notes. DTI will specifically direct concerns to responsible bodies should an FTA commitment requires changes in existing regulations. The relevant bodies will ensure that the measures are consistent with FTAs. The queries concerning FTA commitments are sent to the Department of Trade Negotiation from time to time to ensure compliance.

\subsection{Legal and institutional challenges}

Although the existing framework creates a clear mandate of each institution involved, it may not cope well with the ever-evolving technical standards because a current FTA negotiation tends to cover new technical standards not only for goods but also services and cross-cutting issues such as supply chain and environment. This requires collaborations of both public and private institutions to keep up with new development. In addition, the current framework lacks planning at a pre-negotiation stage. The pre-negotiation strategy helps relevant bodies discuss the direction that they expect from the FTA negotiation to strategize policies and regulations. This prevents potential conflicts and hardships arising out of the FTA implementation.

Another challenge is the lack of monitoring systems. Currently, standards are mainly developed by public bodies with some engagement from industries. As standards are evolving, there is no monitoring procedure to ensure that the standards are up to date or on par with international standards. There is also no review of regulations in place to ensure that they do not lead to trade distortions which potentially jeopardizes the FTA commitments.

\section{Conclusion and policy recommendation}

\subsection{Recommendation for the institutional mechanism of the trade and investment negotiation process}

This article found that the weak link for FTAs negotiations is the lack of FTAs strategy and the FTAs roadmap. The negotiation process is dominated by several interest groups, including large firms. While SMEs have no channel to express their opinion on the process, large enterprises have a strong influence on the Thailand position. This led to the inconsistency of the FTAs strategy and the high domestic pressure against FTAs. The remedy process so far has been unable to enhance the competitiveness and restructure the economy.

Overall recommendations for improving institution mechanism in Thailand in line with stages and progressions of trade and investment agreement are as follows: 


\subsubsection{Pre-and during the actual negotiation}

(1) The government should formulate strategy and create a strategic roadmap for trade and investment negotiations. FTAs negotiation should be included in trade policy.

(2) Specific agency and/or committee should be established to work full-time in FTAs negotiation. Those assigned to work in the proposed agency or committee should be government officials. This agency or committee may include Thailand's Trade Representative (TTR) in their team. TTR should act as the coordinating body linking the negotiation team (government officials) to the Cabinet meeting and to ministers of the relevant ministries. For that reason, TTR must understand all aspects in relation to trade and investment, particularly free-trade. TTR should also be in charge of monitoring the negotiation and making political officials understand the progress of the negotiation.

(3) The government should set up a private sector committee to provide opinions and feedbacks. This committee will serve as a mechanism for private sector engagement and participation before the actual negotiation begins. There should be no more summary session after daily negation; instead, the government may hold the summary session of each negotiation round after round.

\subsubsection{Post-Negotiation}

(4) Monitoring and evaluation of the agreement should be implemented earnestly. There should be the agency responsible to monitor, review, and evaluate all agreements. This agency can be established under the Ministry of Commerce because usually, they are the ones who negotiate and understand the process of the agreement very well. Furthermore, progress reports should be made yearly to follow up, monitor, and evaluate all trade agreements. This can be done in the same way as Singapore's FTA Review and should be reported to Cabinet meetings annually.

(5) The government should institute an agency for promoting FTAs utilization. This agency may be established under the Ministry of Commerce. FTAs utilization should be promoted through different channels to guide businesses on how to take the advantages of FTAs' preferences as the way South Korea and Singapore have done.

(6) Like South Korea, Thailand should have trade remedy measures and establish an agency to mainly provide the remedy to business sectors and entrepreneurs negatively impacted by the agreements. Projects should be designed in such a way that to help them cope with adverse effects as well as to adapt and adjust to the new competitive environment after the agreements came into force.

\subsection{Recommendations for implementation of a specific sector}

This article also found the weak links of implementation and provided policy recommendation for the specific sector as follows:

\section{Technical Barriers to Trade (TBT)}

In Thailand, the Institutional approach in implementing TBT commitments is strictly function-driven. For example, the Department of Trade Negotiation is in charge of FTA 
negotiation. The Thai Industrial Standards Institute (TISI) is responsible for developing technical regulations and standards. Although helping to set a clear role for each institution, this top-down approach is ineffective in keeping up with ever-evolving TBT standards. The TBT negotiations in recent FTAs go beyond standards in goods trade to cover services trade and supply chain. Therefore, other concerning institutions rather than TISI are required to work closely with one another because new development is moving beyond what TISI is accustomed to. The currently fragmented institutional framework does not assist Thailand in coping with new TBT standards being negotiated today. This puts Thailand in the position of a follower lagging behind in trade liberalization.

In Singapore, MTI, as FTA negotiation team, works closely with SPRING (The Standards, Productivity and Innovation Board) in planning a roadmap for TBT negotiation and expected outcomes. This assists the country in making a necessary institutional adjustment before the FTA is actually in force. However, the outcome of an actual FTA negotiation could be different from what is planned in the roadmap. This can make the preparation from the roadmap redundant. Besides, Singapore has advantages in developing technical standards since international standards can be adopted without undergoing a domestic process, which helps to keep the standards up to date with trading partners from around the world. SPRING also conducts a periodical review of regulations and standards to ensure compliance with global trends. Post-Market surveillance is conducted every 5 years to ensure standard compliance. A sanction is imposed on the manufacturer should its goods fails the test.

In South Korea, one of the advantages is that a public institution is assigned to provides a comprehensive knowledge service to industries (i.e., training and coaching) to ensure consistency with FTA commitments and prevent the creation of trade obstacles from using technical regulations. In addition, the Technical Regulatory Impact Assessment (TRIA) is required to assess complementarity with existing and future FTAs. However, the government is the core institution in developing technical regulations and standards which may not reflect real demands from private institutions.

In the USA, the National Institute of Standards and Technology (NIST) was established to ensure that existing technical regulations and standards are consistent with international commitments. There is also a legislation to eliminate regulatory burdens that create obstacles to trade. The review of standards and regulations need to be conducted periodically. With this collaborative institutional approach, the USA is enriched with tools to liberalize the market further. However, since only private institutions are allowed in the process of developing technical standards, this can pave the way for lobbying a standard to benefit a particular group of industries without public monitoring.

The policy recommendations for TBT sector in Thailand are as follows;

(1) TISI should be the main organization conducting a regulatory impact assessment (RIA) with cooperation from other concerning bodies (e.g., National Institute of Metrology, Food and Drug Administration, National Bureau of Agricultural Commodity and Food Standards, etc.) to analyze costs and benefits of existing and future regulations and their compatibility with FTAs. In South Korea, $52 \%$ of all technical standards have been revised to 
align with FTAs after conducting the Technical Regulatory Impact Assessment (TRIA);

(2) TISI should be the main organization providing comprehensive knowledge service of technical standards (i.e., training and coaching) with cooperation from other relevant bodies (e.g., National Institute of Metrology, Food and Drug Administration, National Bureau of Agricultural Commodity and Food Standards, etc.). Since TBT standards in FTAs are very technical, practical errors can lead to inconsistent measures with FTA commitments. The services should be given to all levels of standards practitioners including workers, technicians, and CEOs.

\section{References}

Appellate Body. (2012). Measures concerning the importation, marketing and sale of tuna and tuna products (No. WT/DS381/AB/R). Retrieved December 27, 2017, from https://www.wto.org/english/tratop_e/dispu_e/cases_e/ds381_e.htm

Australia Government - Department of Foreign Affairs and Trade. (2005). Thailand - Australia Free Trade Agreement. Retrieved November 27, 2017, from https://www.dfat.gov.au/trade/agreements/in-force/tafta/Pages/thailand-australia-fta

Cheong, I. (2014). Korea's policy package for enhancing its FTA utilization and implications for Korea's policy (ERIA discussion paper series). Jakarta, Indonesia: ERIA.

Cheong, I. (2017, June 19). Korea's FTA policy: Performance and implications. Paper presented at International Institute for Trade and Development, Bangkok.

Constitution of the Kingdom of Thailand. (1999). National Education Act of B.E. 2542. Retrieved October 27, 2017, from https://asean.org/storage/2016/08/Thailand184.pdf

Constitution of the Kingdom of Thailand. (B.E. 2550). (2007). Retrieved October 27, 2017 , from

http://web.krisdika.go.th/data/outsitedata/outsite21/file/Constitution_of_the_Kingdom_ of_Thailand.pdf

Constitution of the Kingdom of Thailand (B.E. 2557). (2014). Retrieved October 27, 2017, from https://www.ilo.org/dyn/natlex/docs/ELECTRONIC/100483/120552/F1884780617/TH A100483\%20Tha.pdf

Constitution of the Kingdom of Thailand (B.E. 2560). (2017). Retrieved October 29, 2017, from http://constitutionnet.org/sites/default/files/201705/CONSTITUTION+OF+THE+KING DOM+OF+THAILAND+(B.E.+2560+(2017)).pdf

Department of Foreign Trade. (n.d.). Ministry of Commerce's FTA fund. Retrieved October 28, 2017, from http://www.dft.go.th/th-th/dft-service-data-helper

Japan - Thailand Economic Partnership Agreement. (2017). Retrieved September 20, 2017, from https://www.mofa.go.jp/policy/economy/fta/thailand.html

Lee, H. C. (2010). Ratification of a free trade agreement: The Korean legislature's response to globalization. Journal of Contemporary Asia, 40(2), 291-308. doi:10.1080/00472331003600507 
Office of Agricultural Economics. (n.d.). Ministry of Agriculture and Cooperative's FTA fund. Retrieved January 15, 2018, from https://www.devex.com/organizations/office-ofagricultural-economics-oae-thailand-140921

Oxford Public International Law. (1994). Agreement on technical barriers to trade, 1868 U.N.T.S. $120 . \quad$ Retrieved December 22, 2017, from https://opil.ouplaw.com/view/10.1093/law-oxio/e232.013.1/law-oxio-e232

Park, Y. B., \& Moon, S. B. (2006). Korea's FTA policy structure. Paper presented at AKES, RCIE, \& KDI, the Joint Conference on Korea and The World Economy V. Korea University, Seoul, Korean. Retrieved January 20, 2018, from https://faculty.washington.edu/karyiu/confer/seoul06/papers/park-moon.pdf

Solís, M. (2013). South Korea's fateful decision on the Trans-Pacific Partnership. Washington, USA: Brookings Institution.

Thailand - New Zealand Closer Economic Partnership Agreement. (2005). Retrieved October 20, 2017 from https://www.mfat.govt.nz/assets/FTAs-agreements-in-force/ThailandFTA/nz-tha-icep-nationalinterestanalysis.pdf

United States - Thailand Free Trade Agreement. (2006). Retrieved October 15, 2017, from https://nationalaglawcenter.org/wp-content/uploads/assets/crs/RL32314.pdf

World Bank. (n.d.). World development indicators database. Retrieved April 1, 2017, from http://databank.worldbank.org/data/reports.aspx?source=world-development-indicators

World Trade Organization. (2002). European Communities - Trade description of Sardines, report of the Appellate Body, WT/DS231/AB/R. Retrieved March 25, 2018, from http://stage.worldtradelaw.gvpi.net/reports/wtoab/ec-sardines(ab).pdf.download

World Trade Organization. (2014). The WTO agreement series: Technical barriers to trade. Retrieved April 1, 2017, from WTO website: https://www.wto.org/english/res_e/publications_e/tbttotrade_e.pdf

World Trade Organization. (2015). Trade policy review: Thailand. Retrieved April 15, 2017, from WTO website https://www.wto.org/english/tratop_e/tpr_e/s326_e.pdf 